\title{
Estimation of pKa, Analgesic, CNS Depressant Activities of Imidazolinone Derivatives By Correlation With Theoretical Parameters Based on Quantum Chemical Method
}

\author{
Emad A. S. Al-Hyali \\ Chemistry Department, College of Education \\ University of Mosul
}

\section{Received \\ 23/10/2013}

\begin{abstract}
Regression analysis is used for the estimation of the $\mathrm{pKa}$ values, $\%$ analgesic activity (\%AA) and \% decreasing activity of central nervous system (CNS) depressant property (\%DA) of eight substituted imidazolin$5(4 \mathrm{H})$-ones by using various types of descriptors as parameters. These parameters are based on quantum chemical treatments. They were derived by employing semi-empirical calculations represented by Austin model 1 (AM1). The parameters used for representing the variation observed in the pka values, \%AA and \%DA are atomic, structural, and molecular properties, including charges on hetro atoms present in the compounds, energies of HOMO ( $\left.\mathrm{E}_{\mathrm{HOMO}}\right)$ and LUMO (E $\left.\mathrm{E}_{\mathrm{LuMO}}\right)$ orbitals, hardness of molecules $(\eta)$, chemical potential $(\mu)$ electrophilicity index $(\omega)$, total energy (TE), stretch (Str), bend (Bd), 1,4-Vander Waals interactions (1,4VDW), and Non1,4Vander Waals interactions (Non 1,4-VDW). The relation of pKa, \%AA, and $\% \mathrm{DA}$ and each of these parameters of the studied compounds is investigated.
\end{abstract}

Depending on these relations, three sets of parameters were constructed, each of them representing the most sufficiently and reliable set to describe the effect of substituents and structure of imidazolinone under consideration on the studied properties with highly predictive power indicated by high consistency between the calculated and experimental values expressed by correlation coefficient values $\left(\mathrm{R}^{2}\right)$ close to unity and standard error (SE) less than \%5 of the experimental values.

The three sets of parameters were used for the estimation of $\mathrm{pKa}$, $\% \mathrm{AA}$ and \%DA of a number of hypothetical compounds with structures similar to those considered before but with different substituents as a test of 
the validity of the derived parameters. The calculated values were within acceptable range compared with other values found in the literature.

$$
\text { المخلص }
$$

في هذه الدراسة تم استخدام التحليل الانحدار لتقدير قيم pKa و النسبة المئوية لنشاط تسكين الالام) ٪

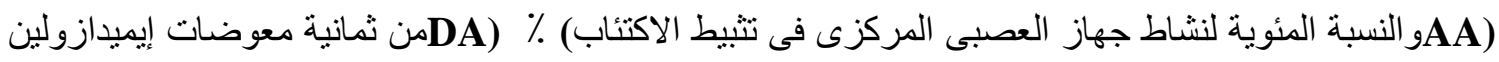
5 (اون من خلال دراسة علاقتها مع أنو اع مختلفة من المتغير ات النظرية المشتقة بالاستناد على طرق كيمياء

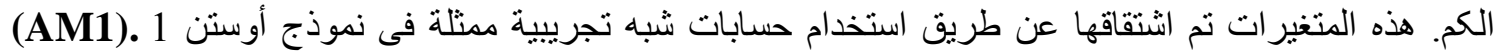

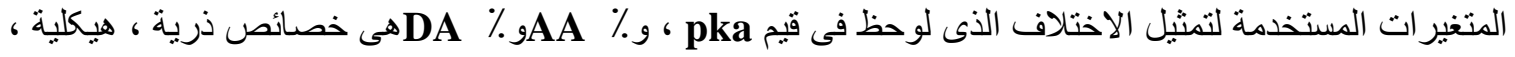
وجزيئية ، ومتضمنة ايضا الثحنات على الذرات غير المتجانسة hetro الموجودة فى المركبات ، وطاقات

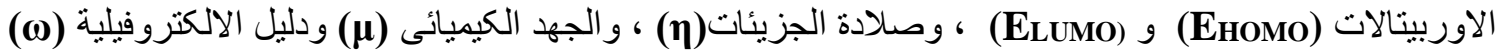
، والطاقة الكلية (TE) ، والمط(Str) ، وطاقة الانحناء (Bd) ، وتداخلات (4) (1) (1) كander Waals)،

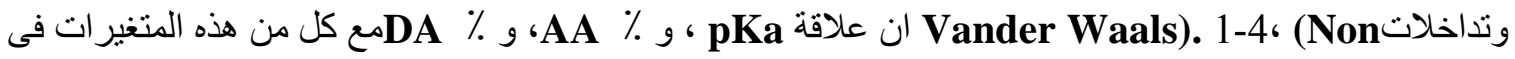

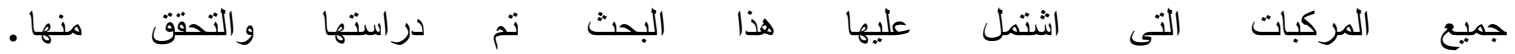
اعتمادا على هذه العلاقات ، تم بناء ثلاث مجاميع من المتغير ات، كل واحدة منهم تمثل المجموعة الأكثر موثوقية بدرجة كافية لوصف تأثير المعوضات وتر اكيب جزيئات الإيميدازولينون قيد الدراسة فى الخصائص الددروسة بقوة تنتؤيه عالية يثار إلى ذلك من خلال التو افق العالى بين القيم المحسوبة والتجرييية و المعبر عنها بواسطة قيم معامل

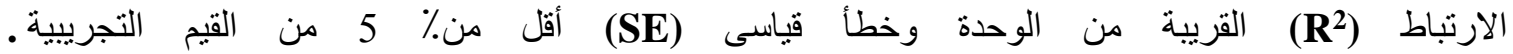

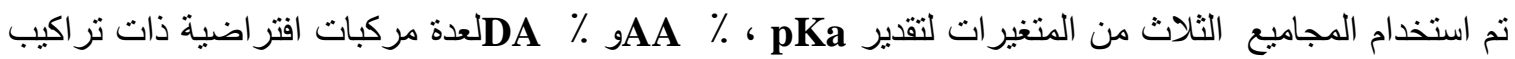
مماتلة لتلك التى اخذت بنظر الاعتبار من قبل ولكن بمعوضات مختلفة كاختبار لصحة المتغيرات المشتقة. كانت

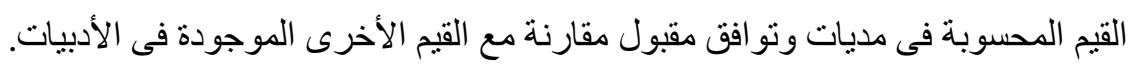

\section{INTRODUCTION}

Imidazolines are compounds containing five member hetro cyclic ring with two nitrogen atoms having the formula $\mathrm{C} 3 \mathrm{H} 6 \mathrm{~N} 2$. The ring involving an imine bond, and the carbons at the 4 and 5 positions are singly bonded [1]. Imidazolines are commonly synthesized from the condensation of 1,2-di amines compounds with nitriles and with ester[2,3].

The substitution on the imidazoline ring provide opportunities for finetuning the electronic and steric properties which influence many of the physicochemical characteristics of the compounds which in turn affect some of their pharmacological activities such as analgesic activity and CNS depressant property $[1,4]$.

Imidazolines are very important type of compounds. They have been 


\section{Emad A. S. Al-Hyali}

investigated as anti-hyperglycemic, anti-inflammatory, anti-hypertensive, anti-hypercholesterolemic, and anti- depressant agents $[1,4]$. They have been used as ligands in Coordination chemistry[2]. Some of the synthesized complexes function as catalysts for reactions such as Henry and Diels Alder reaction [1,2]. Many imidazoline derivatives have also various industrial applications [5].

The pKa values provide basic knowledge for understanding the chemical reactions between compounds (drugs) of interest and pharmacological target. They are therefore represent a very important physicochemical phenomenon that influence the reactivity and spectral properties of the drug compounds and controlling their absorption and action as a result [6].

Analgesic activity and CNS depressant property can be considered as the most important pharmacological activities treated by imidazoline derivatives [7]. The way of the effect of imidazoline compounds on such properties is still ambiguous and not well known and they are roughly evaluated by experimental method. The pKa, analgesic and CNS depressant properties are found to be affected by the nature and location of the substituents exist on the compounds[1,4,8], they are therefore, sensitive to the variation of inductive and steric effects within the molecule. Since such effects can be evaluated by quantum chemical methods [9-12], certain parameters might serve as useful descriptors for understanding the physical and chemical effects of structures of imidazolines on these properties.

In order to find out how far experimental results are reflected in the theoretical predictions and what kind of information can be extracted from such investigation, the present work examines the applicability of quantum chemical parameters derived from the semi-empirical AM1 model as descriptors for affecting the $\mathrm{pKa}$, analgesic and CNS depressant properties of imidazoline derivatives. Several sets of parameters are derived for the theoretical prediction of $\mathrm{pKa}$ values, \%AA and \%DA by simple and multiple regression analysis.

\section{METHOD}

The experimental data ( $\mathrm{pKa}, \% \mathrm{AA}$ and \%DA) are taken from various references [7,13-15]. The $\mathrm{pKa}$ values were calculated in $\% 10$ water and acetone solvent system at $20^{\circ} \mathrm{C}$ by potentiometric method [15]. The analgesic activity was evaluated as acetic acid induced writhing method (\% protection)[15], and the depressant property (\%DA) was estimated by measuring locomotors activity[16] using actophotometer in mice. For evaluation of every pharmacological property, healthy adult albino Swiss mice weighing between 20 - $25 \mathrm{gm}$ and administered intra peritoneally in the 
dose of $100 \mathrm{mg} / \mathrm{Kg}$ body weight.

The structure and collected data of the studied compounds are listed in Table (1). The structures of the selected imidazolinones as illustrated in the figure below:

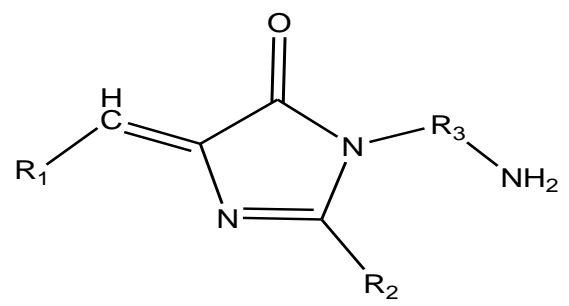

Table (1): pKa, \%AA, and \%DA values[7] of the studied compounds.

\begin{tabular}{|c|c|c|c|c|c|c|}
\hline Comp. No & $\mathrm{R}_{1}$ & $\mathrm{R}_{2}$ & $\mathrm{R}_{3}$ & pKa & \%AA & \%DA \\
\hline 1 & $\mathrm{CH}_{3}$ & $\mathrm{CH}_{3}$ & $\mathrm{CH}_{2} \mathrm{CH}_{2}$ & 3.26 & 44.18 & 52.09 \\
\hline 2 & $\mathrm{CH}_{3}$ & $\mathrm{C}_{6} \mathrm{H}_{5}$ & $\mathrm{CH}_{2} \mathrm{CH}_{2}$ & 5.21 & 35.96 & 39.48 \\
\hline 3 & $\mathrm{C}_{6} \mathrm{H}_{5}$ & $\mathrm{CH}_{3}$ & $\mathrm{CH}_{2} \mathrm{CH}_{2}$ & 4.94 & 65.75 & 42.43 \\
\hline 4 & $\mathrm{C}_{6} \mathrm{H}_{5}$ & $\mathrm{C}_{6} \mathrm{H}_{5}$ & $\mathrm{CH}_{2} \mathrm{CH}_{2}$ & 5.80 & 39.37 & 38.60 \\
\hline 5 & $\mathrm{CH}_{3}$ & $\mathrm{CH}_{3}$ & $\mathrm{C}_{6} \mathrm{H}_{4}$ & 4.99 & 34.25 & 56.29 \\
\hline 6 & $\mathrm{CH}_{3}$ & $\mathrm{C}_{6} \mathrm{H}_{5}$ & $\mathrm{C}_{6} \mathrm{H}_{4}$ & 5.46 & 19.86 & 55.85 \\
\hline 7 & $\mathrm{C}_{6} \mathrm{H}_{5}$ & $\mathrm{CH}_{3}$ & $\mathrm{C}_{6} \mathrm{H}_{4}$ & 5.18 & 56.16 & 56.15 \\
\hline 8 & $\mathrm{C}_{6} \mathrm{H}_{5}$ & $\mathrm{C}_{6} \mathrm{H}_{5}$ & $\mathrm{C}_{6} \mathrm{H}_{4}$ & 6.11 & 22.26 & 52.37 \\
\hline
\end{tabular}

The conformation of the lowest energy of each imidazoline derivatives listed in Table (1) is determined by full geometrical optimization.

The optimized geometries were used for evaluation of atomic charges and structural parameters as total energy (TE), molecular bending (Bd) and stretch (Str), Vander Waals of the type 1,4 (1,4VDW) and (Non 1,4-VDW). Interactions, the highest occupied molecular orbitals energy $\left(\mathrm{E}_{\mathrm{HOMO}}\right)$ and the lowest unoccupied molecular orbital energy $\left(\mathrm{E}_{\mathrm{LUMO}}\right)$. The values of $\mathrm{E}_{\mathrm{HOMO}}$ and $E_{\text {LUMO }}$ were used for the calculations of other molecular properties namely; hardness $(\eta)$, chemical potential $(\mu)$ and electrophilicity index $(\omega)[17,18]$ by employing the following equations:

$$
\begin{aligned}
& \boldsymbol{\eta}=\left(\mathbf{E}_{\text {LUMO }}-\mathbf{E}_{\text {HOMO }}\right) / 2 \\
& \boldsymbol{\mu}=\left(\mathbf{E}_{\text {HOMO }}+\mathbf{E}_{\text {LUMO }}\right) / 2 \\
& \boldsymbol{\omega}=\boldsymbol{\mu}^{2} / \mathbf{2} \boldsymbol{\ldots} \quad \ldots . . . . . . .
\end{aligned}
$$

The Chem. Office program (2004) of Cambridge Software, USA was employed for the performance of conformational analysis and determination of final equilibrium geometries and calculations of all the quantum chemical descriptors.

Multiple Linear Regression (MLR) [19] 


\section{Emad A. S. Al-Hyali}

The experimental $\mathrm{pKa}, \% \mathrm{AA}$, and \%DA were correlated separately with the electronic and structural parameters obtained by quantum chemical calculations. The regression analysis is carried out according to equation (4) by considering the experimental values of (pKa), \%AA and \%DA as dependent variable ( $\mathrm{Y}$ ) and the theoretically calculated parameters as independent variables $(\mathrm{Xi})$.

$$
\mathbf{Y}=\mathbf{b}+\boldsymbol{\Sigma} \mathbf{a}_{\mathbf{i}} \mathbf{X}_{\mathbf{i}}
$$

Where $b$ is a constant and represent a reference value, $a_{i}(s)$, the coefficients of the parameters $\left(\mathrm{X}_{\mathrm{i}}\right)$. The MLR calculations were performed by SPSS package, V.18 for windows. The correlation coefficient $\left(\mathrm{R}^{2}\right)$ and standard error (SE) were utilized as an indication of the linearity and suitability of the chosen model.

\section{RESULTS AND DISCUSSION}

In recent years, several imidazolinon-5(4H)-ones and their derivatives are gaining prominence for their potential pharmacodynamic properties. In view of these observation, it was contemplated to synthesize some novel imidazoline derivatives from respective oxazolinone [20,21].

In this work, the experimental $\mathrm{pKa}$ values, analgesic activity (\%protection to writhing (\%AA)), and percent of decreasing CNS depressant (\%DA) activity of the imidazolinone derivatives considered have been correlated with some descriptors derived by the help of quantum chemical calculations which were basically electronic and energetically related values and they are thought to be capable of describing the effect of substitution on the considered properties successfully. The parameters used as descriptors of the variation of the considered properties are derived by the AM1 method.

In developing model equation for the calculation of the considered properties of the studied imidazolinones, it is reasonable to correlate them with the electronic charges of the hetro atoms of the imidazoline ring in addition to the other hetro atoms exist in their structures $(\mathrm{O}$ of $(\mathrm{C}=\mathrm{O})$ and $\mathrm{N}$ of $\mathrm{NH} 2)$ ) of the studied compounds. Variety of other parameters were considered as descriptors for pKa, \%AA and \%DA listed in Tables (2-3) and were used for correlation in an attempt to find out the parameters providing the best description of the variations of these characteristics.

Additional parameters were also tested related to the energies of HOMO and LUMO orbitals and the values of $\eta, \mu$, and $\omega$ calculated by equations 1,2, and 3 respectively. The values of these parameters are listed in Table (4) .

This study is divided into three parts depending on the statistical analysis and the predictive models build up for correlating the three 


\section{Estimation of pKa, Analgesic, CNS Depressant Activities of ...}

properties considered with the parameters calculated by quantum chemical model and by employing simple and multiple regression analysis methods.

The three properties; pKa, \%AA and \%DA are correlated with the same parameters depending on the knowledge that, the $\mathrm{pKa}$ value is one of the important physicochemical parameter that influences pharmacological activities such as analgesic and CNS depressants activities of the drugs which were proved to be affected by the pKa values [7]. The numbering of atoms in the studied compounds is as indicated below.<smiles>CC=C1N=C(C)N(CC[18NH])C1=O</smiles>

Table (2): Charges on hetro atoms present in compounds 1-8.

\begin{tabular}{|c|c|c|c|c|}
\hline Comp. No & $\mathrm{N} 2$ & $\mathrm{~N} 5$ & $\mathrm{O} 11$ & $\mathrm{~N} 18$ \\
\hline 1 & 0.078 & 0.427 & -0.854 & -0.286 \\
\hline 2 & 0.085 & 0.454 & -0.855 & -0.286 \\
\hline 3 & 0.181 & 0.438 & -0.853 & -0.286 \\
\hline 4 & 0.186 & 0.464 & -0.855 & -0.286 \\
\hline 5 & 0.102 & 0.405 & -0.836 & 0.014 \\
\hline 6 & 0.124 & 0.418 & -0.839 & 0.014 \\
\hline 7 & 0.206 & 0.414 & -0.838 & 0.017 \\
\hline 8 & 0.224 & 0.426 & -0.839 & 0.016 \\
\hline
\end{tabular}




\section{Emad A. S. Al-Hyali}

Table (3): Details of the TE (Kcal/mol) of the compounds 1-8.

\begin{tabular}{|c|c|c|c|c|c|c|c|c|}
\hline $\begin{array}{c}\text { Comp } \\
\text { No }\end{array}$ & TE & Str & Bd & Str-Bd & Tor & $\begin{array}{c}\text { Non1,4 } \\
\text { VDW }\end{array}$ & 1,4 VDW & DD \\
\hline 1 & 59.3162 & 0.6593 & 57.6271 & -0.3076 & 1.4206 & -2.1220 & 8.6114 & -6.5726 \\
\hline 2 & 54.2395 & 0.7925 & 57.5966 & -0.3303 & -4.6999 & -4.1708 & 11.8172 & -6.7658 \\
\hline 3 & 2.3220 & 0.3381 & 9.6268 & 0.0954 & -5.5921 & -2.3496 & 6.4495 & -6.2462 \\
\hline 4 & -1.9556 & 0.4611 & 9.5200 & 0.0775 & -11.6101 & -4.1139 & 9.5240 & -5.8141 \\
\hline 5 & 51.6784 & 0.9038 & 58.4874 & -0.1698 & -9.1267 & -0.6653 & 10.1549 & -7.9063 \\
\hline 6 & 46.3280 & 0.9815 & 58.3617 & -0.2020 & -15.1581 & -2.4624 & 13.2066 & -8.3992 \\
\hline 7 & -5.7713 & 0.6934 & 10.0799 & 0.2743 & -15.8380 & -1.2208 & 7.8733 & -7.6333 \\
\hline 8 & -11.2714 & 0.7394 & 9.8489 & 0.2363 & -21.9828 & -2.9752 & 10.9942 & -8.1025 \\
\hline
\end{tabular}

Table (4): $\mathrm{E}_{\text {HOMO, }} \mathrm{E}_{\mathrm{Lumo}}, \eta, \mu$, and $\omega$ of the compounds 1-8.

\begin{tabular}{|c|c|c|c|c|c|}
\hline $\begin{array}{c}\text { Comp } \\
\text { No }\end{array}$ & $\begin{array}{c}\mathrm{E}_{\text {HOMO }} \\
\text { ev }\end{array}$ & $\begin{array}{c}E_{\text {LUMO }} \\
\text { ev }\end{array}$ & $\eta$ & $\mu$ & $\omega$ \\
\hline 1 & 0.119 & -9.588 & 4.853 & -4.734 & 2.309 \\
\hline 2 & -1.095 & -9.534 & 4.219 & -5.314 & 3.346 \\
\hline 3 & -1.810 & -9.764 & 3.977 & -5.787 & 4.210 \\
\hline 4 & -1.744 & -9.642 & 3.949 & -5.693 & 4.103 \\
\hline 5 & -1.499 & -9.409 & 3.955 & -5.454 & 3.760 \\
\hline 6 & -1.501 & -9.357 & 3.928 & -5.429 & 3.751 \\
\hline 7 & -2.381 & -9.489 & 3.554 & -5.935 & 4.955 \\
\hline 8 & -2.375 & -9.423 & 3.524 & -5.899 & 4.937 \\
\hline
\end{tabular}

\section{Determination of pKa}

As a primary step, correlation among the selected parameters and the $\mathrm{pKa}$ values of the imidazolinones considered for this study, and among the parameters themselves are performed. The statistical results obtained are listed in Table (5).

Looking at the results of Table (5), we may conclude the following: 1 - The values of total energies (TE) of the studied compounds are highly affected by parameters related to the distortion resulted from the bonding among atoms (bend (Bd), stretch- bend (SB) and Torsion (Tor)) and to the atomic charges present on the nitrogen atom (N2) of imidazolinone ring, and also related, to a lower extent, with the parameters indicated to the activity of the reaction behavior of compounds as electrophile or nucleophile $(\mu, \omega)$ and their tendencies to accept electrons (electron affinity $\left(\mathrm{E}_{\mathrm{LUMO}}\right)$ ). 

Emad A. S. Al-Hyali

Table (5): Square correlation coefficients $\left(\mathrm{R}^{2}\right)$ among the parameters evaluated by AM1 of the considered imidazolinones .

\begin{tabular}{|c|c|c|c|c|c|c|c|c|c|c|c|c|c|c|c|c|c|c|}
\hline Parameter & $\mathrm{pKa}$ & $\mathrm{TE}$ & Str & $\mathrm{Bd}$ & SB & Tor & $\begin{array}{l}\text { Non14 } \\
\text { VDW }\end{array}$ & $\begin{array}{c}14 \\
\text { VDW }\end{array}$ & DD & $\begin{array}{c}\mathrm{HOM} \\
\mathrm{O}\end{array}$ & $\begin{array}{c}\text { LUM } \\
\mathrm{O} \\
\end{array}$ & O11 & N5 & N18 & $\mathrm{N} 2$ & $\eta$ & $\mu$ & $\omega$ \\
\hline $\mathrm{pKa}$ & 1 & & & & & & & & & & & & & & & & & \\
\hline $\mathrm{TE}$ & 0.352 & 1 & & & & & & & & & & & & & & & & \\
\hline Str & 0.005 & 0.319 & 1 & & & & & & & & & & & & & & & \\
\hline $\mathrm{Bd}$ & 0.234 & 0.969 & 0.486 & 1 & & & & & & & & & & & & & & \\
\hline SB & 0.296 & 0.938 & 0.188 & 0.874 & 1 & & & & & & & & & & & & & \\
\hline Tor & 0.691 & 0.401 & 0.068 & 0.237 & 0.475 & 1 & & & & & & & & & & & & \\
\hline Non14VDW & 0.123 & 0.014 & 0.078 & 0.020 & 0.013 & 0.001 & 1 & & & & & & & & & & & \\
\hline 14VDW & 0.146 & 0.177 & 0.629 & 0.300 & 0.194 & 0.108 & 0.103 & 1 & & & & & & & & & & \\
\hline DD & 0.079 & 0.012 & 0.679 & 0.073 & 0.004 & 0.378 & 0.239 & 0.302 & 1 & & & & & & & & & \\
\hline HOMO & 0.078 & 0.075 & 0.886 & 0.188 & 0.017 & 0.298 & 0.094 & 0.561 & 0.835 & 1 & & & & & & & & \\
\hline LUMO & 0.076 & 0.651 & 0.009 & 0.514 & 0.716 & 0.720 & 0.004 & 0.003 & 0.106 & 0.027 & 1 & & & & & & & \\
\hline $\mathrm{O} 11$ & 0.115 & 0.014 & 0.410 & 0.001 & 0.104 & 0.476 & 0.449 & 0.079 & 0.833 & 0.642 & 0.269 & 1 & & & & & & \\
\hline N5 & 0.039 & 0.032 & 0.324 & 0.069 & 0.004 & 0.060 & 0.832 & 0.001 & 0.620 & 0.383 & 0.011 & 0.713 & 1 & & & & & \\
\hline N18 & 0.157 & 0.019 & 0.448 & 0.000 & 0.109 & 0.560 & 0.342 & 0.128 & 0.871 & 0.707 & 0.288 & 0.984 & 0.635 & 1 & & & & \\
\hline $\mathrm{N} 2$ & 0.414 & 0.971 & 0.189 & 0.889 & 0.957 & 0.548 & 0.002 & 0.103 & 0.003 & 0.016 & 0.733 & 0.068 & 0.003 & 0.083 & 1 & & & \\
\hline$\eta$ & 0.729 & 0.527 & 0.006 & 0.374 & 0.620 & 0.825 & 0.012 & 0.007 & 0.219 & 0.110 & 0.970 & 0.402 & 0.042 & 0.434 & 0.636 & 1 & & \\
\hline$\mu$ & 0.646 & 0.748 & 0.066 & 0.642 & 0.774 & 0.588 & 0.000 & 0.033 & 0.030 & 0.000 & 0.971 & 0.151 & 0.000 & 0.160 & 0.791 & 0.886 & 1 & \\
\hline$\omega$ & 0.621 & 0.736 & 0.020 & 0.559 & 0.816 & 0.720 & 0.007 & 0.016 & 0.096 & 0.018 & 0.981 & 0.261 & 0.015 & 0.280 & 0.817 & 0.942 & 0.942 & 1 \\
\hline
\end{tabular}


These results may indicate to that, in the studied compounds, the imidazoline ring is not rigid and can be twisted to release the strain imposed upon the ring due to substitution which in turn increasing the activity of the compounds.

The performance of the statistical study according to equation (4) by considering the TE as a dependent variable $(\mathrm{Y})$ and the above mentioned parameters as independent variables $(\mathrm{X} 1, \mathrm{X} 2,----, \mathrm{Xn})$, we could reach to the results listed in Table (6).

Table (6): Multiple regression analysis results to determine the TE .

\begin{tabular}{|c|c|c|c|c|c|}
\hline $\mathrm{Y}$ & $\mathrm{X}$ & Coefficient $\left(\mathrm{a}_{\mathrm{i}}\right)$ & $\mathrm{SE}$ & $\mathrm{R}^{2}$ & Constant $(\mathrm{b})$ \\
\hline $\mathrm{TE}$ & $\mathrm{Bd}$ & 1.063 & 0.35 & 1 & -2.973 \\
& $\mathrm{Tor}$ & 0.841 & & & \\
\hline $\mathrm{TE}$ & $\mathrm{Bd}$ & 0.595 & 1.37 & 0.999 & 45.421 \\
& $\mathrm{~N} 2$ & -278.021 & & & \\
\hline $\mathrm{TE}$ & $\mathrm{N} 2$ & -614.535 & 3.23 & 0.996 & 106.219 \\
& $\mathrm{Tor}$ & -0.896 & & & \\
\hline $\mathrm{TE}$ & $\mathrm{Bd}$ & 1.002 & 3.68 & 0.995 & 2.766 \\
& $\mathrm{E}_{\mathrm{LUMO}}$ & 8.042 & & & \\
\hline $\mathrm{TE}$ & $\mathrm{Bd}$ & 0.976 & 4.47 & 0.985 & 83.643 \\
& $\mu$ & 16.668 & & & \\
\hline $\mathrm{TE}$ & $\mathrm{Bd}$ & 0.987 & 0.28 & 1.000 & 4.888 \\
& $\mathrm{~N} 2$ & -44.550 & & & \\
& Tor & 0.713 & & & \\
\hline
\end{tabular}

According to the results of Table (6), the most suitable description of the TE can be represented by equation (5).

$\mathrm{TE}=4.888+0.987 \mathrm{Bd}-44.550 \mathrm{~N} 2+0.713$ Tor

2-The stretch (Str) of the structures of the studied compounds is mostly affected by the ionization potentials of the molecules $\left(\mathrm{E}_{\text {Hомо }}\right)$, dipoledipole (DD) interactions and Vander Waals interactions of the (1,4VDW) type.

3-The 1,4VDW interactions are affected by the atomic charges present on N5 and N18 atoms, while the Non1,4VDW interactions are not active or not present in the considered compounds.

4-The DD interactions of the studied compounds are better expressed by atomic charges of the atoms O11, N5 and N18.

5 -The $\mathrm{E}_{\text {Hомо }}$ is mostly affected and related to atomic charges of $\mathrm{O} 11$ and $\mathrm{N} 18$, and the $\mathrm{E}_{\mathrm{LUmO}}$ showed good correlation with charges exist on $\mathrm{N} 2$ atom, $\mu$ and $\omega$.

The above mentioned discussion could give some explanations 
about the active positions in the considered compounds which could be the main reason of the activity and behavior of such compounds as drugs and representing the points by which such compounds attacking the treated targets during their biological activity. The results could also help us for performing our study by choosing the suitable parameters for relating the above values of $\mathrm{pKa}, \% \mathrm{AA}$ and $\% \mathrm{DA}$.

According to the above results, multiple linear regression analysis are carried out for producing a set of parameters that could help for calculating the pKa of such compounds theoretically. The results of regression analysis for the determination of $\mathrm{pKa}$ theoretically are listed in Table (7)

Table (7): Regression analysis results for calculating pKa theoretically.

\begin{tabular}{|c|c|c|c|}
\hline Y & Parameter (X) & $\mathrm{R}^{2}$ & SE \\
\hline $\mathrm{pKa}$ & $\mathrm{E}_{\text {LuMO, }}$ Tor & 0.756 & 0.497 \\
\hline $\mathrm{pKa}$ & $\mathrm{E}_{\text {LUMO }}, \mathrm{N} 2$ & 0.728 & 0.525 \\
\hline $\mathrm{pKa}$ & ELUMO, $_{\text {L5 }}$ & 0.789 & 0.463 \\
\hline $\mathrm{pKa}$ & $\mathrm{E}_{\text {LUMO}}, \mathrm{O} 11$ & 0.719 & 0.534 \\
\hline $\mathrm{pKa}$ & $\mathrm{E}_{\text {LUMO }}, \mathrm{N} 18$ & 0.710 & 0.542 \\
\hline $\mathrm{pKa}$ & $\mathrm{E}_{\text {LUMO }}, \mathrm{E}_{\text {HOMO }}$ & 0.727 & 0.527 \\
\hline $\mathrm{pKa}$ & $\mathrm{E}_{\mathrm{LUMO}}, \mathrm{N} 2, \mathrm{~N} 5$ & 0.846 & 0.442 \\
\hline $\mathrm{pKa}$ & $\mathrm{E}_{\text {LUMO }}, \mathrm{N} 5, \mathrm{O} 11$ & 0.961 & 0.222 \\
\hline $\mathrm{pKa}$ & $\mathrm{E}_{\text {LUMO }}, \mathrm{N} 5, \mathrm{~N} 18$ & 0.949 & 0.225 \\
\hline $\mathrm{pKa}$ & $\mathrm{E}_{\mathrm{LUMO}}, \mathrm{N} 5, \mathrm{E}_{\mathrm{HOMO}}$ & 0.952 & 0.247 \\
\hline $\mathrm{pKa}$ & ELUMO, N5, O11, 14VDW & 0.982 & 0.174 \\
\hline $\mathrm{pKa}$ & $\mathrm{E}_{\mathrm{LUMO}}, \mathrm{N} 5, \mathrm{O} 11, \mathrm{DD}$ & 0.973 & 0.214 \\
\hline $\mathrm{pKa}$ & $\mathrm{E}_{\text {LUMO }}, \mathrm{N} 5, \mathrm{O} 11$, Non14VDW & 0.970 & 0.226 \\
\hline $\mathrm{pKa}$ & $\mathrm{E}_{\mathrm{LUMO}}, \mathrm{N} 5, \mathrm{O} 11, \mathrm{E}_{\mathrm{HOMO}}$ & 0.961 & 0.255 \\
\hline $\mathrm{pKa}$ & $\mathrm{E}_{\text {LUMO }}, \mathrm{N} 5, \mathrm{O} 11, \mathrm{~N} 2$ & 0.966 & 0.240 \\
\hline $\mathrm{pKa}$ & $\mathrm{E}_{\text {LUMO }}, \mathrm{N} 5, \mathrm{O} 11, \mathrm{~N} 18$ & 0.961 & 0.255 \\
\hline $\mathrm{pKa}$ & $\mathrm{E}_{\text {номо }}, \mathrm{N} 5, \mathrm{O} 11, \mathrm{~N} 2$ & 0.955 & 0.276 \\
\hline $\mathrm{pKa}$ & $\mathrm{E}_{\text {LUMO }}, \mathrm{N} 5, \mathrm{O} 11, \mathrm{TE}$ & 0.970 & 0.227 \\
\hline $\mathrm{pKa}$ & $\mathrm{E}_{\text {LUMO }}, \mathrm{N} 5, \mathrm{O} 11, \mathrm{Str}$ & 0.964 & 0.245 \\
\hline $\mathrm{pKa}$ & $\mathrm{E}_{\text {LUMO }}, \mathrm{N} 5, \mathrm{O} 11, \mathrm{Bd}$ & 0.972 & 0.219 \\
\hline $\mathrm{pKa}$ & $\mathrm{E}_{\text {LUMO }}, \mathrm{N} 5, \mathrm{O} 11, \mathrm{SB}$ & 0.975 & 0.204 \\
\hline $\mathrm{pKa}$ & $\mathrm{E}_{\text {LUMO }}, \mathrm{N} 5, \mathrm{O} 11$, Tor & 0.961 & 0.257 \\
\hline $\mathrm{pKa}$ & $\mathrm{E}_{\text {LUMO }}, \mathrm{N} 5, \mathrm{O} 11, \omega$ & 0.986 & 0.180 \\
\hline $\mathrm{pKa}$ & $\mathrm{E}_{\text {LUMO }}, \mathrm{N} 5, \mathrm{O} 11,14 \mathrm{VDW}, \eta$ & 0.996 & 0.102 \\
\hline $\mathrm{pKa}$ & $\mathrm{E}_{\mathrm{LUMO}}, \mathrm{N} 5, \mathrm{O} 11,14 \mathrm{VDW}, \mu$ & 0.995 & 0.109 \\
\hline
\end{tabular}

The results of Table (7) showed that, the best parameters those correlating to the $\mathrm{pKa}$ values giving best correlation coefficient 
$\left(\mathrm{R}^{2}=0.996\right)$ and lowest standard error $(\mathrm{SE}=0.102)$ could be expressed by equation (5).

\section{$\mathrm{pKa}=66.357-4.008 \mathrm{E}_{\mathrm{LUMO}}+46.129 \mathrm{N5}+140.026 \mathrm{O11}+0.194$ (14VDW) $+7.333 \eta$

Equation (5) shows that, the pKa of the compounds considered in the regression analysis is more susceptible to the changes of the charges present on $\mathrm{O} 11$ and $\mathrm{N} 5$ atoms. Comparison between the observed $\mathrm{pKa}$ [7] with those estimated by equation (5) is presented in Table (8).

Table(8): Comparison between the observed and calculated pKa, \%AA, and \%DA by using equations (5), (6), and (7) respectively.

\begin{tabular}{|c|c|c|c|c|c|c|c|c|c|}
\hline $\begin{array}{c}\text { Comp } \\
\text { No }\end{array}$ & $\begin{array}{c}\text { Obs. } \\
\mathrm{pKa}\end{array}$ & $\begin{array}{c}\text { Calc. } \\
\mathrm{pKa}\end{array}$ & Res* & $\begin{array}{c}\text { Obs. } \\
\text { \%AA }\end{array}$ & $\begin{array}{c}\text { Calc } \\
\% \mathrm{AA}\end{array}$ & Res* & $\begin{array}{c}\text { Obs } \\
\% \mathrm{DA}\end{array}$ & $\begin{array}{c}\text { Calc } \\
\% \mathrm{DA}\end{array}$ & Res* \\
\hline 1 & 3.26 & 3.27 & -0.01 & 44.18 & 44.23 & -0.05 & 52.09 & 51.87 & 0.22 \\
\hline 2 & 5.21 & 5.21 & 0.00 & 35.96 & 37.36 & -1.4 & 39.48 & 40.14 & -0.66 \\
\hline 3 & 4.94 & 4.95 & -0.01 & 65.75 & 66.40 & -0.65 & 42.43 & 43.09 & -0.66 \\
\hline 4 & 5.80 & 5.85 & -0.05 & 39.37 & 37.80 & 1.93 & 38.60 & 37.50 & 1.1 \\
\hline 5 & 4.99 & 4.97 & 0.02 & 34.25 & 35.17 & -0.92 & 56.29 & 56.18 & 0.11 \\
\hline 6 & 5.46 & 5.55 & -0.09 & 19.86 & 17.49 & 2.37 & 55.85 & 55.38 & 0.47 \\
\hline 7 & 5.18 & 5.26 & -0.08 & 56.16 & 54.52 & 1.64 & 56.15 & 55.33 & 0.82 \\
\hline 8 & 6.11 & 6.03 & 0.08 & 22.26 & 25.15 & -2.89 & 52.37 & 53.76 & -1.39 \\
\hline
\end{tabular}

$*$ Res $=$ Obs-Calc

The results of Table (8) showed good consistency between the experimental and calculated values of $\mathrm{pKa}$ of the studied compounds with percent of error lower than $\% 5$ which is within the accepted range of error.

\section{Determination of Analgesic and CNS Depressant Activities}

The treatment of analgesic and CNS depressant are inseparable as activities. Several studies have been designed to evaluate the CNS depressant (\%DA) and analgesic (\%AA) activities of a variety of diseases[22] by employing various medicinal plant extract. The beneficial of medicinal effect of plant extract materials typically results from the combination of secondary products present in plant which are capable of producing definite physiological action on body [23,24].

It is worth to mention here that, the \%AA is calculated as protection to writings whereas the $\% \mathrm{DA}$ is estimated as change of decreasing activity.

In order to perform this study, simple and multiple linear regression analysis have been carried out by considering each of \%AA and \%DA as dependent variable in separate treatment and the parameters listed in Table (5) as independent variables. The results of regression analysis (R2 and SE) are shown in Tables (9) and (10). The values of the coefficients 
of the parameters $\left(a_{i}\right)$ for the best are introduced as in equations 6 , and 7 .

Table (9): Regression analysis results for calculating \%AA

\begin{tabular}{|c|c|c|c|}
\hline Y & Parameter $(\mathrm{X})$ & $\mathrm{R}^{2}$ & SE \\
\hline$\% \mathrm{AA}$ & $\mathrm{N} 2$ & 0.033 & 16.60 \\
\hline$\% \mathrm{AA}$ & N5 & 0.017 & 16.74 \\
\hline$\% \mathrm{AA}$ & O11 & 0.148 & 15.58 \\
\hline$\% \mathrm{AA}$ & N18 & 0.209 & 15.02 \\
\hline$\% \mathrm{AA}$ & $\mathrm{E}_{\text {Номо }}$ & 0.616 & 10.46 \\
\hline$\%$ AA & $\mathrm{E}_{\text {LUMO }}$ & 0.000 & 16.88 \\
\hline$\% \mathrm{AA}$ & TE & 0.086 & 16.14 \\
\hline$\% \mathrm{AA}$ & Str & 0.555 & 11.26 \\
\hline$\% \mathrm{AA}$ & $\mathrm{Bd}$ & 0.183 & 15.26 \\
\hline$\% \mathrm{AA}$ & SB & 0.085 & 16.15 \\
\hline$\% \mathrm{AA}$ & Tor & 0.193 & 15.16 \\
\hline$\%$ AA & Non14VDW & 0.050 & 16.45 \\
\hline$\% \mathrm{AA}$ & 14VDW & 0.858 & 6.36 \\
\hline$\% \mathrm{AA}$ & DD & 0.357 & 13.53 \\
\hline$\% \mathrm{AA}$ & $\mathrm{H}$ & 0.015 & 16.76 \\
\hline$\% \mathrm{AA}$ & $\mu$ & 0.023 & 16.68 \\
\hline$\% \mathrm{AA}$ & $\Omega$ & 0.004 & 16.85 \\
\hline$\% \mathrm{AA}$ & $\mathrm{E}_{\mathrm{HOMO}}, \mathrm{Str}$ & 0.617 & 11.45 \\
\hline$\% \mathrm{AA}$ & $\mathrm{E}_{\mathrm{HOMO}}, 14 \mathrm{VDW}$ & 0.877 & 6.49 \\
\hline$\% \mathrm{AA}$ & $\mathrm{E}_{\text {номо, }}, \mathrm{DD}$ & 0.703 & 10.08 \\
\hline$\% \mathrm{AA}$ & $\mathrm{E}_{\mathrm{HOMO}}, 14 \mathrm{VDW}, \mathrm{DD}$ & 0.879 & 7.19 \\
\hline$\% \mathrm{AA}$ & $\mathrm{E}_{\mathrm{HOMO}}, 14 \mathrm{VDW}, \mathrm{DD}, \mathrm{Str}$ & 0.921 & 6.73 \\
\hline$\% \mathrm{AA}$ & $\mathrm{E}_{\text {номо }}, 14 \mathrm{VDW}, \mathrm{Str}$ & 0.917 & 5.96 \\
\hline$\% \mathrm{AA}$ & $\mathrm{E}_{\mathrm{HOMO}}, 14 \mathrm{VDW}, \mathrm{Str}, \mathrm{N} 2$ & 0.980 & 3.39 \\
\hline$\% \mathrm{AA}$ & $\mathrm{E}_{\mathrm{HOMO}}, 14 \mathrm{VDW}, \mathrm{Str}, \mathrm{TE}$ & 0.985 & 2.88 \\
\hline$\% \mathrm{AA}$ & $\mathrm{E}_{\mathrm{HOMO}}, 14 \mathrm{VDW}, \mathrm{Str}, \mathrm{Bd}$ & 0.986 & 2.80 \\
\hline$\% \mathrm{AA}$ & $\mathrm{E}_{\text {Номо }}, 14 \mathrm{VDW}$, Str, N5 & 0.924 & 6.60 \\
\hline
\end{tabular}


Emad A. S. Al-Hyali

Table (10): Regression analysis results for calculating \%DA

\begin{tabular}{|c|c|c|c|}
\hline Y & Parameter (X) & $\mathrm{R}^{2}$ & SE \\
\hline$\% \mathrm{DA}$ & $\mathrm{N} 2$ & 0.000 & 8.30 \\
\hline$\% \mathrm{DA}$ & N5 & 0.915 & 2.42 \\
\hline$\% \mathrm{DA}$ & O11 & 0.729 & 4.32 \\
\hline$\% \mathrm{DA}$ & N18 & 0.698 & 4.56 \\
\hline$\% \mathrm{DA}$ & $\mathrm{E}_{\mathrm{HOMO}}$ & 0.525 & 5.72 \\
\hline$\% \mathrm{DA}$ & $\mathrm{E}_{\text {LUMO }}$ & 0.007 & 8.27 \\
\hline$\% \mathrm{DA}$ & $\mathrm{TE}$ & 0.024 & 8.20 \\
\hline$\% \mathrm{DA}$ & Str & 0.408 & 6.38 \\
\hline$\% \mathrm{DA}$ & $\mathrm{Bd}$ & 0.066 & 8.02 \\
\hline$\% \mathrm{DA}$ & SB & 0.005 & 8.28 \\
\hline$\% \mathrm{DA}$ & Tor & 0.120 & 7.79 \\
\hline$\% \mathrm{DA}$ & Non14VDW & 0.654 & 4.88 \\
\hline$\% \mathrm{DA}$ & 14VDW & 0.024 & 8.20 \\
\hline$\% \mathrm{DA}$ & DD & 0.684 & 4.66 \\
\hline$\% \mathrm{DA}$ & $\eta$ & 0.041 & 8.13 \\
\hline$\% \mathrm{DA}$ & $\mu$ & 0.002 & 8.29 \\
\hline$\% \mathrm{DA}$ & $\omega$ & 0.012 & 8.25 \\
\hline$\% \mathrm{DA}$ & $\mathrm{N} 5, \mathrm{O} 11$ & 0.922 & 2.53 \\
\hline$\% \mathrm{DA}$ & $\mathrm{N} 5, \mathrm{~N} 18$ & 0.930 & 2.41 \\
\hline$\% \mathrm{DA}$ & $\mathrm{E}_{\mathrm{HOMO}}, \mathrm{N} 5$ & 0.943 & 2.16 \\
\hline$\% \mathrm{DA}$ & N5, Str & 0.928 & 2.44 \\
\hline$\% \mathrm{DA}$ & N5, Non14VDW & 0.939 & 2.25 \\
\hline$\% \mathrm{DA}$ & N5, DD & 0.929 & 2.41 \\
\hline$\% \mathrm{DA}$ & $\mathrm{E}_{\mathrm{HOMO}}, \mathrm{N} 5$, Non14VDW & 0.944 & 2.40 \\
\hline$\% \mathrm{DA}$ & $\mathrm{E}_{\text {HOMO }}, \mathrm{N} 5, \mathrm{~N} 18$ & 0.943 & 2.42 \\
\hline$\% \mathrm{DA}$ & $\mathrm{E}_{\mathrm{HOMO}}, \mathrm{N} 5, \mathrm{O} 11$ & 0.944 & 2.39 \\
\hline$\% \mathrm{DA}$ & $\mathrm{E}_{\mathrm{HOMO}}, \mathrm{Str}, \mathrm{N} 5$ & 0.952 & 2.22 \\
\hline$\% \mathrm{DA}$ & $\mathrm{E}_{\mathrm{HOMO}}, \mathrm{N} 5, \mathrm{DD}$ & 0.947 & 2.34 \\
\hline$\% \mathrm{DA}$ & $\mathrm{E}_{\mathrm{HOMO}}, \mathrm{Str}, \mathrm{N} 5, \mathrm{O} 11$ & 0.983 & 1.51 \\
\hline$\% \mathrm{DA}$ & $\mathrm{E}_{\text {Hомо }}, \mathrm{Str}, \mathrm{N} 5, \mathrm{~N} 18$ & 0.975 & 1.85 \\
\hline$\% \mathrm{DA}$ & $\mathrm{E}_{\mathrm{HOMO}}, \mathrm{Str}, \mathrm{N} 5$, Non14VDW & 0.953 & 2.55 \\
\hline$\% \mathrm{DA}$ & $\mathrm{E}_{\text {Hомо }}$, Str, N5, DD & 0.961 & 2.31 \\
\hline$\% \mathrm{DA}$ & $\mathrm{E}_{\mathrm{HOMO}}, \mathrm{Str}, \mathrm{N} 5, \eta$ & 0.981 & 1.63 \\
\hline$\% \mathrm{DA}$ & $\mathrm{E}_{\text {HOMO }}, \mathrm{Str}, \mathrm{N} 5, \mu$ & 0.981 & 1.63 \\
\hline$\% \mathrm{DA}$ & $\mathrm{E}_{\mathrm{HOMO}}, \mathrm{Str}, \mathrm{N} 5, \omega$ & 0.978 & 1.75 \\
\hline$\% \mathrm{DA}$ & $\mathrm{E}_{\mathrm{HOMO}}, \mathrm{Str}, \mathrm{N} 5, \mathrm{O} 11, \mathrm{~N} 18$ & 0.988 & 1.57 \\
\hline
\end{tabular}

According to the results in Table (9), the best set of parameters correlated to the \%AA is given by equation (6). 


\section{\%АA = -2881.443 - 298.959 Е Номо - 6.44 (14VDW) + 224.512 Str $-0.578 B d$ (6)}

Comparison between the experimental \%AA[7] of the considered imidazolinones and the values calculated by using equation (6) are listed in Table (8). Good consistency is noticed between these values.

Looking carefully on the comparison presented in Table (8), we see that, if compound number (1) is considered as a reference, the insertion of a phenyl group into position (R2) will increase the steric factor causing distortion of the ring shape and creating deviation between the observed and calculated \%AA, while replacing the $\mathrm{CH}_{3}$ group of (R1) by phenyl will not show this effect since the ring in position (R1) has more room and freedom to rotate itself and minimize the strain that may result from the steric effect. The size and nature of group (R3) on the nitrogen atom is very important to the activity spectrum. For this reason, these compounds may operate by different mechanism and therefore relieve a different sharper kind of pain.

According to the regression analysis results presented in Table(10), the best estimation of the \%DA may be given by equation (7); with $\mathrm{R}^{2}=0.988$ and $\mathrm{SE}=1.57$.

\section{\%DA=-402.765-479.43N5 + 58.003 $\mathrm{E}_{\text {номО }}-\mathbf{2 5 . 4 2 6} \mathrm{Str}-\mathbf{1 4 6 2 . 5 2 8} \mathrm{O11}$ $+58.563 \mathrm{~N} 18$

Comparison between the observed values of \%DA [7] and the calculated ones (by equation (7)) showed good agreement (Table (8)).

The results of Table (8) indicate that, there is a clear deviation between the observed and calculated (\%DA) due to steric effect especially when inserting phenyl ring into position (R2) similar to the trend seen when calculating the \%AA.

By employing compounds of analogues structure to the imidazolinones compounds selected for this study, we have made an effort to test the validity of the selected parameters aiming for improving the \%AA and/or to reduce depressing effect (\%DA) by assuming the presence of a number of hypothetical compounds introduced in a random fashion depending on the ease of synthesis and the logic of the variation pattern of the results obtained. The hypothetical compounds assumed for this study differ from the imidazolinone compounds considered by varying the R1, R2 and R3 groups with more bulkier groups such as ethyl, isopropyl, t-butyl and naphthyl groups (Table (11)). The calculated theoretical parameters of these compounds depending on the AM1 model are listed in Table (12). The calculated pKa, \%AA and \%DA of these compounds are portrayed in Table (11) . 
Table (11): Values of pKa, \%AA and \%DA of the hypothetical compounds calculated by using equation (5), (6) and (7) respectively.

\begin{tabular}{|c|c|c|c|c|c|c|}
\hline $\begin{array}{c}\text { Comp. } \\
\text { No }\end{array}$ & $\mathrm{R} 1$ & $\mathrm{R} 2$ & $\mathrm{R} 3$ & $\mathrm{pKa}$ & $\% \mathrm{AA}$ & $\% \mathrm{DA}$ \\
\hline 9 & $\mathrm{CH}_{3}$ & $\mathrm{C}_{2} \mathrm{H}_{5}$ & $\mathrm{CH}_{2} \mathrm{CH}_{2}$ & 13.84 & 58.62 & 21.53 \\
\hline 10 & $\mathrm{CH}_{3}$ & Isopropyl & $\mathrm{CH}_{2} \mathrm{CH}_{2}$ & 14.03 & 39.09 & 26.72 \\
\hline 11 & $\mathrm{CH}_{3}$ & t-butyl & $\mathrm{CH}_{2} \mathrm{CH}_{2}$ & 13.74 & 90.24 & 23.64 \\
\hline 12 & $\mathrm{C}_{2} \mathrm{H}_{5}$ & $\mathrm{CH}_{3}$ & $\mathrm{CH}_{2} \mathrm{CH}_{2}$ & 13.29 & 56.50 & 24.13 \\
\hline 13 & Isopropyl & $\mathrm{CH}_{3}$ & $\mathrm{CH}_{2} \mathrm{CH}_{2}$ & 13.24 & 85.64 & 21.72 \\
\hline 14 & t-butyl & $\mathrm{CH}_{3}$ & $\mathrm{CH}_{2} \mathrm{CH}_{2}$ & 12.66 & 98.78 & 23.53 \\
\hline 15 & $\mathrm{CH}_{3}$ & $\mathrm{Naphthyl} \mathrm{CH}_{2} \mathrm{CH}_{2}$ & 14.84 & 20.64 & 26.61 \\
\hline 16 & $\mathrm{CH}_{3}$ & $\mathrm{CH}_{3}$ & $\mathrm{Naphthyl}$ & 18.99 & 46.45 & 9.03 \\
\hline 17 & $\mathrm{CH}_{3}$ & $\mathrm{NO}_{2}$ & $\mathrm{CH}_{2} \mathrm{CH}_{2}$ & 17.30 & -37.99 & 14.71 \\
\hline 18 & $\mathrm{CH}_{3}$ & $\mathrm{Cl}$ & $\mathrm{CH}_{2} \mathrm{CH}_{2}$ & 11.91 & 59.25 & 32.38 \\
\hline
\end{tabular}

Table (12):Values of parameters calculated by AM1 for the hypothetical compounds employed for performing this study.

\begin{tabular}{|c|c|c|c|c|c|c|c|c|c|c|}
\hline \multirow{2}{*}{ Paramet. } & \multicolumn{10}{|c|}{ Compound Number } \\
\cline { 2 - 13 } & 9 & 10 & 11 & 12 & 13 & 14 & 15 & 16 & 17 & 18 \\
\hline TE & 70.375 & 72.350 & 74.238 & 69.682 & 70.855 & 70.718 & 64.194 & 54.778 & 73.717 & 69.258 \\
\hline Str & 1.299 & 1.374 & 1.7670 & 1.296 & 1.589 & 1.722 & 1.513 & 1.398 & 1.144 & 1.206 \\
\hline Bd & 68.974 & 69.700 & 70.060 & 68.761 & 68.520 & 68.621 & 71.129 & 61.975 & 69.034 & 68.730 \\
\hline SB & -0.624 & -0.566 & -0.466 & -0.602 & -0.600 & -0.470 & -0.514 & -0.711 & -0.626 & -0.673 \\
\hline Tor & 0.221 & 1.178 & 1.055 & 0.267 & 0.422 & 0.220 & -15.011 & -15.432 & 1.163 & 1.077 \\
\hline $\begin{array}{c}\text { Non14 } \\
\text { VDW }\end{array}$ & -2.274 & -3.121 & -2.711 & -2.206 & -2.906 & -2.898 & -1.373 & -1.062 & -1.733 & -1.516 \\
\hline 14VDW & 8.768 & 9.847 & 10.603 & 8.140 & 9.831 & 9.530 & 14.670 & 12.581 & 7.819 & 7.493 \\
\hline DD & -5.988 & -6.061 & -6.068 & -5.974 & -6.001 & -6.006 & -6.220 & -3.971 & -6.168 & -7.059 \\
\hline CD* & - & - & - & - & - & - & - & - & 3.086 & - \\
\hline N2 & -0.564 & -0.567 & -0.562 & -0.564 & -0.566 & -0.565 & -0.532 & -0.527 & -0.545 & -0.636 \\
\hline N5 & 0.408 & 0.403 & 0.401 & 0.410 & 0.409 & 0.409 & 0.409 & 0.379 & 0.457 & 0.393 \\
\hline O11 & -0.773 & -0.769 & -0.770 & -0.776 & -0.776 & -0.778 & -0.773 & -0.731 & -0.720 & -0.780 \\
\hline N18 & -0.286 & -0.286 & -0.286 & -0.286 & -0.286 & -0.286 & -0.286 & 0.031 & -0.287 & -0.286 \\
\hline E 18 HOM & -9.181 & -9.084 & -8.971 & -9.162 & -9.075 & -9.012 & -9.024 & -9.134 & -8.954 & -9.225 \\
\hline ELUMO & -4.524 & -4.539 & -4.552 & -4.438 & -4.402 & -4.350 & -5.646 & -4.636 & -5.674 & -4.028 \\
\hline H & 2.328 & 2.272 & 2.237 & 2.362 & 2.336 & 2.331 & 1.689 & 2.249 & 1.640 & 2.589 \\
\hline
\end{tabular}

$* \mathrm{CD}=$ Charge-Dipole interaction

The results obtained (Table (11)) indicate the following :

1-The replacement of (R1 and R2) by more electron donating groups increasing the basicity of such compounds and presuming a clear steric effect especially when substituting the t-butyl group in R2 position. The replacement of $\mathrm{CH}_{3}$ group with a naphthyl ring ( compounds number 15 and16) increases the torsion on the molecules and creating higher effect 
on the pKa value and producing more basic impounds. The importance of such studies lies in that, a knowledge of ionization constants of compounds is of great importance in the drug discovery process. These constants can have a profound effect on the physicochemical properties of a compound and are therefore essential for optimization of absorption, distribution, metabolism and excretion characteristics[25]. The knowledge of ionization state of a compound is also required for determining the correct binding site interaction that occur and the development of reliable structure-acidity relationships.

2-The alkylation has powerful effect in which as the alkyl group is increased in size from a methyl to t-butyl groups, the activity of depressant drops and the \%AA recovers and increases, but when a naphthyl group is attached to the imidazoline ring instead of $\mathrm{CH}_{3}$, both the \%AA and \%DA are decreased. Explanation of these variations could be attributed to that, the side groups substituents have electronic effect on the imidazoline ring in addition to steric effect. Whether the side chain was electron withdrawing or donating electrons, it will affect the basicity (and activity as a result) of the ring and affect the compound ability as a drug to reach the receptor in the target body.

The success of such study could be evaluated by the high correlation coefficient $\left(\mathrm{R}^{2}\right)$ and lower standard error (SE) obtained from the statistical analysis, in addition to the calculated values of the properties which lie within the same range of other experimental values of compounds with similar structures found in the literature[7].

An important advantage of such study is that, the activity of drugs could be estimated by varying several substituents theoretically before testing it on the experimental animals.

It is important to appreciate that, there are other factors can be responsible for the efficiency of drug activity to reach the target to be treated. Since the active compound might be metabolized to other inactive compound before reaches the receptor, or alternatively, might be distributed more efficiently to one part of the body than the other. Therefore, the improvement of the activity is due to pharmacodynamic properties of these drugs rather their affinity for the analgesic receptors. In other words, it reflects how much the drug can reach the receptor rather than how well it bind to it.

\section{REFERENCES}

1- H. Liu, and D. M. Du.; (2009); 'Recent Advances in the Synthesis of 2-Imidazolines and Their Applications in Homogeneous Catalysis"; Adv. Synth. Catal.; 351, 489-519.

2- N. MacInnes and S. Duty (2004). "Locomotor effects of imidazoline I2-site-specific ligands and monoamine oxidase 
inhibitors in rats with a unilateral 6-hydroxydopamine lesion of the nigrostriatal pathway"; Br J Pharmacol; 143 (8), 952-959.

3- R. D. Crouch, (2009), "Synthetic routes toward 2-substituted 2imidazolines". Tetrahedron; 65, 2387-2397.

4- C. Dardonville, and I. Rozas; (2004); "Imidazoline binding sites and their ligands: An overview of the different chemical structures"; Med. Res. Rev., 24, 639-661.

5- R. Tyagi, V. K. Tyagi, S. K. Pandey; (2007); "Imidazoline and its derivatives: an overview"; J. Oleo. Sci.; 56(5), 211-222.

6- S. Jelfs, P. Ertl, and P. Selzer; (2007); "Estimation of $\mathrm{pKa}$ for Druglike Compounds Using Semiempirical and Information-Based Descriptors"; J. Chem. Inf. Model; 47, 450-459.

7- J. K. Gupta, Biplab De, and V. S. Saravanan; (2006); "Correlation between $\mathrm{pKa}$ and pharmacological properties of some imidazolin$5(4 \mathrm{H})$-ones, their precursor and Schiff bases"; Indian J. Chemistry; V. 4B, 2580-2582.

8- T. H. Lowry, K. S. Richardson; (1987); "Mechanism and Theory in Organic Chemistry"; 3rd. ed.; Harper Collins; New York,1987.

9- K. C. Gross, P.G. Seybold, Z. Peralta-Inga, and P. Politzer; (2001); J. Org. Chem.; 66, 6919.

10- K. C. Gross, P.G. Seybold; (2000); Int. J. Quantum Chem.; 80, 1107.

11-K. C. Gross, P.G. Seybold, C. M. Hadad; (2002); Int. J. Quantum Chem.; 90, 445.

12-K. C. Gross, P.G. Seybold; (2001); Int. J. Quantum Chem.; 85, 569.

13- J. K. Gupta, Biplab De, and V. S. Saravanan; (2005); Indian J. Pharm. Scs.; 67, 373.

14- Biplab De, and J. K. Gupta; (2003); Indian J. Pharm. Educ.; 37, 100.

15- L. Wittkin, C. F. Heubuer, F. Galdi, E. O'keefe, P. Spitaletta, and A. J. Plummer; (1961); J. Pharmacol Expt. Therap.; 133, 400.

16-S. K. Kulkarni; (1996); Hand book of pharmacology (Vallabh, Prakashan, Dellhi); 41-43.

17- R. G. Parr, and R. G. Pearson; (1983); J. Am. Chem. Soc., 105, 7512.

18- R. P. Iczkowski, J. L. Margrave; (1961); J. Am. Chem. Soc., 83, 3547.

19- J. Shorter; (1982); "Correlation analysis of organic chemistry"; Research studies Press: New York.

20- B. S. Funiss, A. J. Hanford, P. W. Smith, and A. R. Tatchell; (1996); "Practical organic chemistry", (ELBS Longman Singapore); 1155-1156. 
21-V. S. Saravanan, B. De, and J. K. Gupta; (2004); "Synthesis and antimicrobial activity of some 4-substituted -2-phenyl oxazol 5(4H)-one derivatives"; $91^{\text {st }}$ The Indian Science Congress (Punjab University groups; Chandigarh) 3-7 January.

22-M. S. Rakh,S. R. Chaudhari; (2010); " Evaluation of CNS depressant activity of Momordica dioica Roxb willd fruit pulp"; Int J Pharm Pharm Sci; 2, 124-126.

23- M. A. Hossen, I. Jahan, M. Abdullah, A. Mamun, JAM S. Sakir, M. Shamimuzzaman, M. J. Uddin, and M. E. Haque; (2013); "CNS depressant and analgesic activities of Okra (Abelmoschus esculentus Linn.)"; Molecular \& Clinical Pharmacology; 4(1), 4452.

24- B. Joshi, S. Lekhak, A. Sharma; (2009); “ Antibacterial property of different medicinal plants: Ocimum sanctum, Cinnamomum zeylanicum, Xanthoxylum armatum and Origanum majorana. Kathmandu University"; J Sci Eng Tech 5, 143-150.

25-S. Jelfs, P. Ertl, and P. Selzer;(2007); "Estimation of $\mathrm{pKa}$ for Drug like Compounds Using Semi empirical and Information-Based Descriptors"; J. Chem. Inf. Model.; 47, 450-459. 